\title{
Alpha-1 Antitrypsin Deficiency and Risk of Lung Cancer in Never-Smokers: A Multicentre Case- Control Study
}

\section{Ramón Antonio Tubío-Pérez}

Pulmonary Department, Hospital Álvaro Cunqueiro, EOXI Vigo; NeumoVigo I+i Research Group, Vigo Biomedical Research Institute (IBIV), Galicia, Spain.

\section{María Torres-Durán ( $\nabla$ maria.luisa.torres.duran@sergas.es )}

Pulmonary Department, Hospital Álvaro Cunqueiro, EOXI Vigo; NeumoVigo I+i Research Group, Vigo Biomedical Research Institute (IBIV), Galicia, Spain.

\section{María Esmeralda García-Rodríguez}

Pulmonary Department, Hospital Álvaro Cunqueiro, EOXI Vigo; NeumoVigo I+i Research Group, Vigo Biomedical Research Institute (IBIV), Galicia, Spain.

\section{Cristina Candal-Pereira}

Department of Preventive Medicina and Public Health, University of Santiago de Compostela, Spain; CIBER de Epidemiología y Salud Pública, CIBERESP, Spain.

\section{Julia Rey-Brandariz}

Department of Preventive Medicina and Public Health, University of Santiago de Compostela, Spain; CIBER de Epidemiología y Salud Pública, CIBERESP, Spain.

\section{Mónica Pérez-Ríos}

Department of Preventive Medicina and Public Health, University of Santiago de Compostela, Spain; CIBER de Epidemiología y Salud Pública, CIBERESP, Spain.

\section{Juan Barros-Dios}

Department of Preventive Medicina and Public Health, University of Santiago de Compostela, Spain; CIBER de Epidemiología y Salud Pública, CIBERESP, Spain.

\section{Alberto Fernández-Villar}

Pulmonary Department, Hospital Álvaro Cunqueiro, EOXI Vigo; NeumoVigo I+i Research Group, Vigo Biomedical Research Institute (IBIV), Galicia, Spain.

\section{Alberto Ruano-Raviña}

Department of Preventive Medicina and Public Health, University of Santiago de Compostela, Spain; CIBER de Epidemiología y Salud Pública, CIBERESP, Spain.

\section{Research Article}

Keywords: alpha-1 antitrypsin, lung cancer, never-smokers 
Posted Date: December 6th, 2021

DOI: https://doi.org/10.21203/rs.3.rs-1032507/v1

License: (a) (i) This work is licensed under a Creative Commons Attribution 4.0 International License. Read Full License

Version of Record: A version of this preprint was published at BMC Cancer on January 19th, 2022. See the published version at https://doi.org/10.1186/s12885-022-09190-3. 


\section{Abstract \\ Background}

Lung cancer (LC) is the most commonly diagnosed cancer and the leading cause of cancer-related death in both sexes worldwide. Although its principal risk factor is smoking habit, there are genetic mutations, such as alpha- 1 antitrypsin deficiency (AATD), that have been related with increased risk This study is the continuation of an earlier one published by the same group in 2015, aimed at analysing risk of LC in neversmokers, associated with carriers of the AATD genotype.

\section{Methods}

A multicentre case-control study was conducted in Spain across the period January 2011 to August 2019. Cases were patients with LC, and controls were patients, all never-smokers, undergoing major non-cancerrelated surgery. Data were collected on epidemiological characteristics, exposure to environmental tobacco smoke (ETS), residential radon levels, and alpha-1 antitrypsin (AAT) genotype.

\section{Results}

The study included 457 cases (42\%) and 631 controls (58\%), with a predominance of women. The most frequent histological type was adenocarcinoma (77.5\%), followed by squamous cell carcinoma $(7.7 \%)$. No association of risk of LC was found with the status of AATD genotype carrier, both overall and broken down by age, sex, or exposure to ETS.

\section{Conclusions}

No risk association was found between being a carrier of an AAT deficiency genotype and LC among neversmokers. Even so, new studies are required to provide fuller information in this regard with respect to neversmokers, and possibly even include previous respiratory diseases.

\section{Background}

Lung cancer (LC) is the most commonly diagnosed cancer and the leading cause of cancer-related death in both sexes worldwide $(1,2)$. Currently it has an estimated 5-year survival rate of $13-20 \%(3)$. Smoking habit is its principal risk factor, followed by exposure to radon, which is the second leading LC risk factor globally, and the leading LC risk factor among never-smokers (4).

LC among never-smokers has increased in incidence, accounting for $15 \%$ of all lung cancers in the USA in recent years (5). It displays characteristics that distinguish it from LC in smokers, including a number of genes (6) and their protein products, which could act at different levels in the process of carcinogenesis and tumour progression. Among these is alpha- 1 antitrypsin $($ AAT $)(7,8)$, which is a glycoprotein synthesized 
primarily by hepatocytes ( $80 \%$ ) and, to a lesser extent, by other cells such as monocytes, macrophages or neoplastic cells among others (9). It is encoded by the SERPINA1 gene, located in the long arm of chromosome 14 (10), and is transmitted by autosomal co-dominant Mendelian inheritance (11). The PiM allele (Pi: protease inhibitor) is considered normal in structure and function (12), and is present in $85-90 \%$ of the Caucasian population (13). Over 125 different allelic variants of this gene have been described: among these, the most frequent deficiency alleles are the PiS and PiZ alleles, with a frequency in Caucasians of 3$10 \%$ and $1-3 \%$, and plasma concentrations of around $60 \%$ and $20 \%$ of normal values, respectively (14). The principal action of AAT is inhibition of serine protease, with neutrophil elastase being the most important at a tissular level (15). Other properties described are anti-inflammatory, antimicrobial and immunomodulatory activity $(16,17)$, which has led to establish the possible involvement of AAT in the development and progression of different types of neoplasms $(18)$, including LC $(7,19)$. The organ most commonly affected by AATD in adults is the lung, through the development of emphysema, especially among individuals with exposure to tobacco smoke (20).

Some studies have analysed the possible relationship between AATD and lung cancer, with uneven results $(21,22)$. A recent systematic review (23), which included 6 studies and a total of more than 4,000 patients, suggests that AATD could increase the risk of LC, and adenocarcinoma and squamous cell carcinoma in particular. This risk would increase with exposure to tobacco smoke and in individuals with diagnosis of COPD. Yet, there is only one study conducted on never-smokers which indicates an increased risk of LC associated with homozygous S-allele carriers (OR: $4.6495 \%$ 95\% confidence interval $(\mathrm{Cl})=1.08-19.92)$. This risk is higher in women (OR: 7.58: $95 \% \mathrm{Cl} 1.40-40.87$ ) and in subjects with exposure to environmental tobacco smoke (ETS) (OR: 12.10; $95 \% \mathrm{Cl} 1.18-123.77$ ). This same study, undertaken by our group, is the only study to have taken exposure to residential radon into account (24).

The main aim of the present study was to analyse whether the fact of being a carrier of an AAT deficiency genotype increases the risk of LC among never-smokers. The secondary objectives were to analyse whether there might be differences in the result, on stratifying by age, sex and exposure to ETS.

We present the following article in accordance with the STROBE reporting checklist.

\section{Methods}

We designed a multicentre hospital-based case-control study at 7 hospitals situated in north-east Spain (6 in Galicia and 1 in Asturias). The study participants were recruited across the period January 2011 to August 2019: cases were never-smoker patients histologically diagnosed with LC at the participating hospitals, and controls were never-smokers undergoing non-cancer-related surgery, most commonly major ambulatory surgery. Controls were enrolled using frequency sampling by sex and age with respect to cases. There were no restrictions in terms of sex, and all participants were over the age of 35 years. A neversmoker was defined as someone who had smoked $<100$ cigarettes per lifetime or $<1$ cigarette/day during a maximum of 6 months. 
At the time of their inclusion in the study, all participants answered a survey, which included questions about the characteristics of their daily lives, with special stress on exposure to ETS. Exposure to ETS was defined as having cohabited with a smoker for a minimum of 20 years. Participants were asked about their personal relationship with the smoker, i.e., years of cohabitation and number of cigarettes/day smoked by the coinhabitant. An Alpha-track radon detector was delivered to all participants and placed in their bedrooms for the purpose of taking readings for a minimum period of 3 months. All detectors were read at and the results were then obtained from the Galicia Radon Laboratory (www.radon.gal), a facility certified by the Spanish National Accreditation Body (Entidad de Acreditación Nacional) for taking these types of measurements. All methods were carried out in accordance with relevant guidelines and regulations. (11) The study protocol was approved by the Galician Ethics Committee (2010/295).

\section{Laboratory analysis}

A specimen of $3 \mathrm{ml}$ of whole blood was taken from all the study subjects for determination of genetic polymorphisms, including AAT deficiency alleles $\mathrm{S}$ and $\mathrm{Z}$ for genotyping. All samples were analysed by the National Genotyping Centre (Centro Nacional de Genotipado) at the University of Santiago de Compostela using the MassARRAY iPLEX GOLD SNP genotyping system (Sequenom Inc., San Diego, CA) in accordance with the manufacturer's instructions. This method has been described by Buetow et al. (25)

\section{Statistical analysis}

Firstly, we conducted a bivariate analysis describing the characteristics of age, sex, educational level, exposure to ETS, residential radon concentrations, and distribution of the $S$ or $Z$ mutations of AAT with respect participants' case or control status. A logistic regression was then performed, in which the dependent variable was case or control status, and the independent variable was being a homozygous or heterozygous S- or Z-allele carrier. The same analysis was performed by reference to age of over or under 65 years, and in women and men. Lastly, we analysed whether the risk of LC for patients with AAT deficiency alleles was different according to their exposure to ETS. Results were expressed as Odds Ratios with $95 \% \mathrm{Cl}$. All analyses were performed using the SPSS computer software package version 20.

\section{Results}

The study covered 457 cases and 631 controls. The characteristics of the participants are shown in Table 1: the median age of cases was slightly higher than that of controls, with a clear predominance of women (79.6\%); $39.6 \%$ of cases and $31.7 \%$ of controls had residential radon concentrations $\geq 200 \mathrm{~Bq} / \mathrm{m}^{3} ; 41.1 \%$ of cases had experienced exposure to ETS in the home during the preceding 20 years; $77 \%$ of cases were adenocarcinomas; $19.9 \%$ of cases and $26.6 \%$ of controls were carriers heterozygous for the $S$ allele versus $2 \%$ of cases and $1.6 \%$ of controls who were homozygous for the $S$ allele. In the case of the $Z$ allele, $3.7 \%$ of cases and $4 \%$ of controls were heterozygous carriers, with no subject being a homozygous carrier. 
Table 1

Characteristics of individuals included in the study.

\begin{tabular}{|lll|}
\hline Variable & Cases, $\mathbf{n}(\%)$ & Controls, $\mathbf{n}(\%)$ \\
\hline $\mathrm{N}$ & $457(42)$ & $631(58)$ \\
\hline Median age (P25 - P75) & $70(61-78)$ & $66(58-75)$ \\
\hline Gender & & \\
\hline Female & $364(79.6)$ & $429(68.0)$ \\
\hline Male & $93(20.4)$ & $202(32.0)$ \\
\hline Educational level & & \\
\hline No formal education & $156(34.1)$ & $177(28.1)$ \\
\hline Primary education & $210(46.0)$ & $293(46.4)$ \\
\hline Secondary education & $44(9.6)$ & $86(13.6)$ \\
\hline University education & $47(10.3)$ & $75(11.9)$ \\
\hline Exposure to residential radon (Bq/m $\left.{ }^{3}\right)$ & & \\
\hline$<200$ & $276(60.4)$ & $431(68.3)$ \\
\hline$\geq 200$ & $181(39.6)$ & $200(31.7)$ \\
\hline Exposure to environmental tobacco smoke & & \\
\hline Yes & $193(42.2)$ & $259(41.0)$ \\
\hline No & $264(57.8)$ & $372(59.0)$ \\
\hline Histological type & & \\
\hline Adenocarcinoma & $357(78.1)$ & $453(71.8)$ \\
\hline Squamous cell carcinoma & $35(7.7)$ & \\
\hline Small-cell carcinoma & $28(6.1)$ & \\
\hline Large-cell carcinoma & & \\
\hline Other histological types & & \\
\hline AAT mutations & & \\
\hline PI*S & & \\
\hline Not present & & \\
\hline Heterozygous & & \\
\hline
\end{tabular}

ETS: environmental tobacco smoke. AAT: alpha-1 antitryps 


\begin{tabular}{|lcl|}
\hline Variable & Cases, $\mathbf{n}(\%)$ & Controls, $\mathbf{n}(\%)$ \\
\hline Homozygous & $9(2.0)$ & $10(1.6)$ \\
\hline $\mathrm{P}{ }^{\star} \mathrm{Z}$ & & \\
\hline Not present & $440(96.3)$ & $606(96.0)$ \\
\hline Heterozygous & $17(3.7)$ & $25(4.0)$ \\
\hline Homozygous & 0 & 0 \\
\hline ETS: environmental tobacco smoke. AAT: alpha-1 antitryps & \\
\hline
\end{tabular}

Table 2 shows the analysis of risk of LC associated with different genotypes, exposure to ETS, and residential radon levels. No significant increase was observed in risk of LC with any of the genotypes analysed, and risk among homozygous subjects was no higher than among heterozygous subjects. Similarly, no increased risk of LC was found to be associated with exposure to ETS or residential radon concentrations $\geq 200 \mathrm{~Bq} / \mathrm{m}^{3}$. 
Table 2

AAT genotype and adjusted risk of LC.

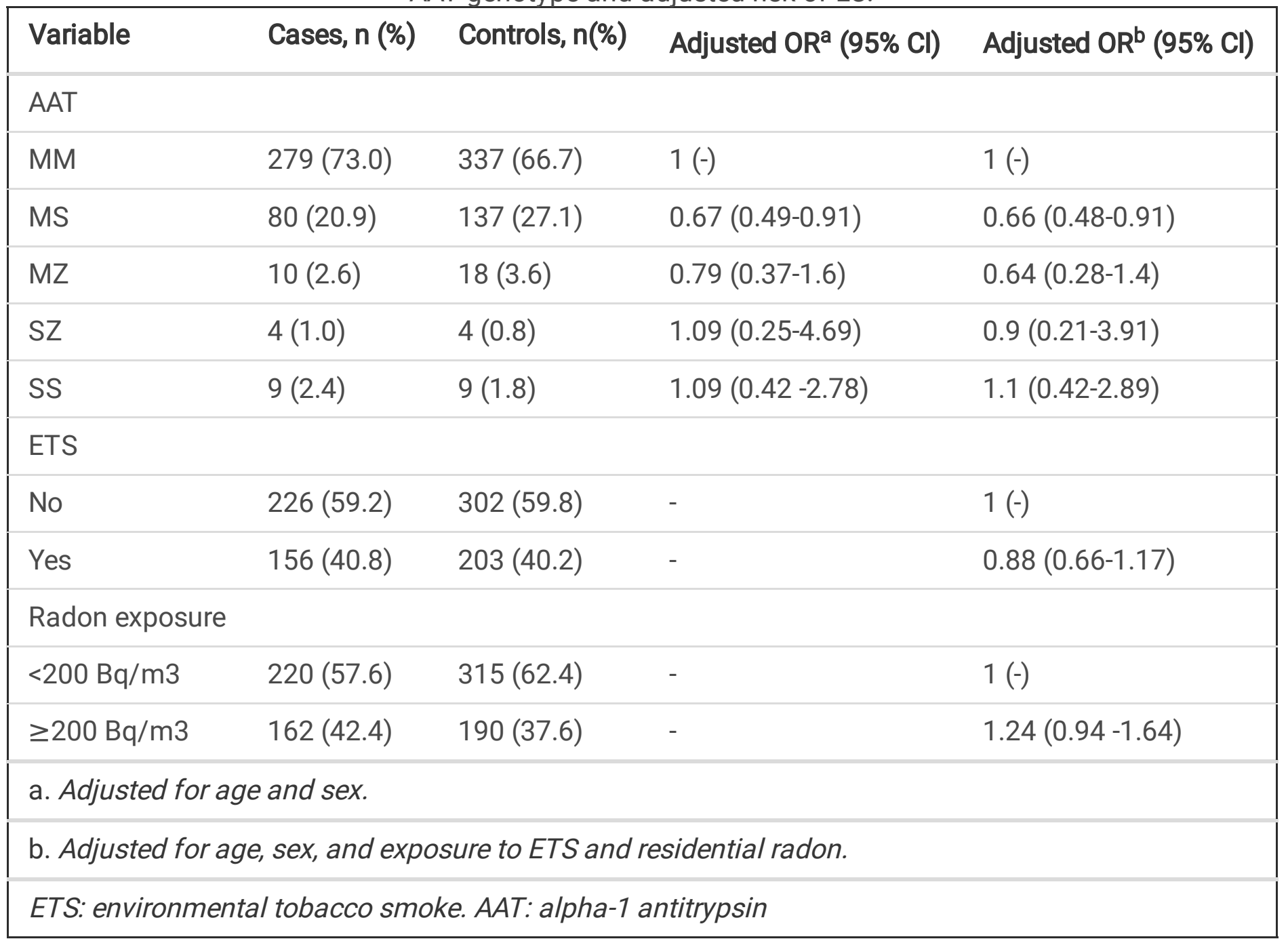

Table 3 shows the characteristics of cases who were homozygous carriers of the SS genotype. These were 9 patients having a median age of 68 years (62-85), 88\% women. Presence of emphysema in LC was found in none of the cases. The mean pulmonary function values were as follows: FEV1 (forced expiratory volume in the first second) $1.694 \mathrm{ml}$; FEV1 105.4\%; and DLCO (diffusing capacity of the lung for carbon monoxide) $81 \%$. The most frequent histology was adenocarcinoma ( $55 \%$ ), followed by squamous cell carcinoma (45\%). 
Table 3

Characteristics of lung cancer cases among carriers of the $\mathrm{PI}$ *S genotype

\begin{tabular}{|ll|}
\hline Cases $(\mathbf{n})$ & $\mathbf{9}$ \\
\hline Median age (IQR) & 68 (62-85) yrs \\
\hline Women (\%) & 88 \\
\hline Emphysema (\%) & 0 \\
\hline FEV1 (ml) & 1694 \\
\hline FEV1(\%) & 105.4 \\
\hline DLCO(\%) & 81 \\
\hline Histology (\%) & Adenocarcinoma (55) \\
& Squamous cell carcinoma (45) \\
\hline
\end{tabular}

Table 4 analyses risk by sex and age. In the case of women, no association was observed with the different AAT genotypes, with the adjusted OR for the SS genotype being 1.19 (95\% $\mathrm{Cl} 0.42-3.48)$. Along these same lines, no association was found between risk and any of the AATD genotypes among men. The analysis of risk by age showed no association between risk and any of the genotypes in the different age groups, though it should be noted that individuals aged under 65 years who were carriers of the SS genotype registered an OR of $6.24(95 \% \mathrm{Cl} 0.88-124.59)$. 
Table 4

Relationship between AAT genotype and risk of lung cancer, by sex and age.

\section{AAT genotype and risk of $\mathrm{LC}$ among women never-smokers \\ AAT genotype and risk of LC among men never-smokers}

\begin{tabular}{|c|c|c|c|c|c|c|c|c|}
\hline Variable & $\begin{array}{l}\text { Cases, } \\
\mathrm{n}(\%)\end{array}$ & $\begin{array}{l}\text { Controls, } \\
n(\%)\end{array}$ & $\begin{array}{l}\text { Adjusted } \\
\mathrm{OR}^{\mathrm{a}} \\
(95 \% \mathrm{Cl})\end{array}$ & $\begin{array}{l}\text { Adjusted } \\
\text { OR }^{\mathrm{b}} \\
(95 \% \mathrm{Cl})\end{array}$ & $\begin{array}{l}\text { Cases, } \\
\mathrm{n}(\%)\end{array}$ & $\begin{array}{l}\text { Controls, } \\
\mathrm{n}(\%)\end{array}$ & $\begin{array}{l}\text { Adjusted } \\
\text { OR }^{\mathrm{a}} \\
(95 \% \mathrm{Cl})\end{array}$ & $\begin{array}{l}\text { Adjusted } \\
\text { OR }^{\mathrm{b}} \\
(95 \% \mathrm{Cl})\end{array}$ \\
\hline \multicolumn{9}{|c|}{$\begin{array}{l}\text { Alpha-1 } \\
\text { antitrypsin }\end{array}$} \\
\hline MM & $\begin{array}{l}215 \\
(71.4)\end{array}$ & $\begin{array}{l}222 \\
(64.5)\end{array}$ & $1(-)$ & $1(-)$ & $\begin{array}{l}64 \\
(79)\end{array}$ & $\begin{array}{l}115 \\
(71.4)\end{array}$ & $1(-)$ & $1(-)$ \\
\hline MS & $\begin{array}{l}65 \\
(21.6)\end{array}$ & $\begin{array}{l}98 \\
(28.5)\end{array}$ & $\begin{array}{l}0.66 \\
(0.46- \\
0.93)\end{array}$ & $\begin{array}{l}0.66 \\
(0.46- \\
0.96)\end{array}$ & $\begin{array}{l}15 \\
(18.5)\end{array}$ & $\begin{array}{l}39 \\
(24.2)\end{array}$ & $\begin{array}{l}0.73 \\
(0.38- \\
1.36)\end{array}$ & $\begin{array}{l}0.67 \\
(0.33- \\
1.29)\end{array}$ \\
\hline$M Z$ & $9(3)$ & $15(4.4)$ & $\begin{array}{l}0.78 \\
(0.36- \\
1.65)\end{array}$ & $\begin{array}{l}0.64 \\
(0.26- \\
1.49)\end{array}$ & $1(1.2)$ & $3(1.9)$ & $\begin{array}{l}0.85 \\
(0.04- \\
7.05)\end{array}$ & $\begin{array}{l}0.74 \\
(0.04- \\
6.21)\end{array}$ \\
\hline SZ & $4(1.3)$ & $2(0.6)$ & $\begin{array}{l}1.97 \\
(0.38- \\
14.38)\end{array}$ & $\begin{array}{l}1.70 \\
(0.32- \\
12.47)\end{array}$ & $0(0)$ & $2(1.2)$ & - & - \\
\hline SS & $8(2.7)$ & $7(2)$ & $\begin{array}{l}1.14 \\
(0.41- \\
3.17)\end{array}$ & $\begin{array}{l}1.19 \\
(0.42- \\
3.48)\end{array}$ & $1(1.2)$ & $2(1.2)$ & $\begin{array}{l}0.87 \\
(0.04- \\
9.37)\end{array}$ & $\begin{array}{l}0.7(0.03 \\
-7.55)\end{array}$ \\
\hline
\end{tabular}

\section{ETS}

exposure

$\begin{array}{lllllllll}\text { No } & 158 & 176 & - & 1(-) & 68 & 126 & - & 1(-) \\ & (52.5) & (51.2) & & & (84) & (78.3) & & \\ \text { Yes } & 143 & 168 & - & 0.94 & 13 & 35 & - & 0.67 \\ & (47.5) & (48.8) & & (0.68- & (16) & (21.7) & & (0.32- \\ & & & & 1.29) & & & & 1.36)\end{array}$

Radon

exposure

$\begin{array}{lllllllll}<200 & 171 & 225 & - & 1(-) & 49 & 90 & - & 1(-) \\ \mathrm{Bq} / \mathrm{m}^{3} & (56.8) & (65.4) & & & (60.5) & (55.9) & \\ >=200 & 130 & 119 & - & 1.43 & 32 & 71 & - & 0.87(0.5 \\ \mathrm{Bq} / \mathrm{m}^{3} & (43.2) & (34.6) & & \begin{array}{l}(1.03- \\ 1.97)\end{array} & (39.5) & (44.1) & & -1.53)\end{array}$

AAT genotype and risk of LC in persons aged $<65$ years

AAT genotype and risk of LC in persons aged over 65 years 


\begin{tabular}{|c|c|c|c|c|c|c|c|c|}
\hline \multirow[b]{2}{*}{ Variable } & \multicolumn{4}{|c|}{$\begin{array}{l}\text { AAT genotype and risk of LC among } \\
\text { women never-smokers }\end{array}$} & \multicolumn{4}{|c|}{$\begin{array}{l}\text { AAT genotype and risk of LC among men } \\
\text { never-smokers }\end{array}$} \\
\hline & $\begin{array}{l}\text { Cases, } \\
\text { n (\%) }\end{array}$ & $\begin{array}{l}\text { Controls, } \\
\text { n (\%) }\end{array}$ & $\begin{array}{l}\text { Adjusted } \\
\text { OR }^{\mathrm{a}} \\
(95 \% \mathrm{Cl})\end{array}$ & $\begin{array}{l}\text { Adjusted } \\
\text { OR }^{\mathrm{b}} \\
(95 \% \mathrm{Cl})\end{array}$ & $\begin{array}{l}\text { Cases, } \\
\mathrm{n}(\%)\end{array}$ & $\begin{array}{l}\text { Controls, } \\
\mathrm{n}(\%)\end{array}$ & $\begin{array}{l}\text { Adjusted } \\
\text { OR }^{\mathrm{a}} \\
(95 \% \mathrm{Cl})\end{array}$ & $\begin{array}{l}\text { Adjusted } \\
\text { OR }^{\mathrm{b}} \\
(95 \% \mathrm{Cl})\end{array}$ \\
\hline \multicolumn{9}{|c|}{$\begin{array}{l}\text { Alpha-1 } \\
\text { antitrypsin }\end{array}$} \\
\hline MM & $\begin{array}{l}99 \\
(75.6)\end{array}$ & $\begin{array}{l}155 \\
(69.2)\end{array}$ & $1(-)$ & $1(-)$ & $\begin{array}{l}180 \\
(71.7)\end{array}$ & $\begin{array}{l}182 \\
(64.8)\end{array}$ & $1(-)$ & $1(-)$ \\
\hline MS & $\begin{array}{l}22 \\
(16.8)\end{array}$ & $\begin{array}{l}60 \\
(26.8)\end{array}$ & $\begin{array}{l}0.61 \\
(0.36- \\
1.02)\end{array}$ & $\begin{array}{l}0.55 \\
(0.31- \\
0.95)\end{array}$ & $\begin{array}{l}58 \\
(23.1)\end{array}$ & $\begin{array}{l}77 \\
(27.4)\end{array}$ & $\begin{array}{l}0.72 \\
(0.49- \\
1.05)\end{array}$ & $\begin{array}{l}0.74 \\
(0.49- \\
1.1)\end{array}$ \\
\hline $\mathrm{MZ}$ & $5(3.8)$ & $7(3.1)$ & $\begin{array}{l}0.92 \\
(0.27- \\
2.74)\end{array}$ & $\begin{array}{l}1.15 \\
(0.33- \\
3.76)\end{array}$ & $5(2)$ & $11(3.9)$ & $\begin{array}{l}0.67 \\
(0.26- \\
1.66)\end{array}$ & $\begin{array}{l}0.41 \\
(0.13- \\
1.17)\end{array}$ \\
\hline$S Z$ & $1(0.8)$ & $1(0.4)$ & $\begin{array}{l}1.50 \\
(0.06- \\
38.35)\end{array}$ & $\begin{array}{l}1.16 \\
(0.04- \\
30.11)\end{array}$ & $3(1.2)$ & $3(1.1)$ & $\begin{array}{l}1.17 \\
(0.21- \\
6.49)\end{array}$ & $\begin{array}{l}1(0.18- \\
5.53)\end{array}$ \\
\hline SS & $4(3.1)$ & $1(0.4)$ & $\begin{array}{l}3.26 \\
(0.62- \\
23.94)\end{array}$ & $\begin{array}{l}6.24 \\
(0.88- \\
124.59)\end{array}$ & $5(2)$ & $8(2.8)$ & $\begin{array}{l}0.66(0.2 \\
-2.03)\end{array}$ & $\begin{array}{l}0.63 \\
(0.19- \\
1.93)\end{array}$ \\
\hline \multicolumn{9}{|l|}{$\begin{array}{l}\text { ETM } \\
\text { exposure }\end{array}$} \\
\hline No & $\begin{array}{l}76 \\
(58)\end{array}$ & $\begin{array}{l}134 \\
(59.8)\end{array}$ & - & $1(-)$ & $\begin{array}{l}150 \\
(59.8)\end{array}$ & $\begin{array}{l}168 \\
(59.8)\end{array}$ & - & $1(-)$ \\
\hline Yes & $\begin{array}{l}55 \\
(42)\end{array}$ & $\begin{array}{l}90 \\
(40.2)\end{array}$ & - & $\begin{array}{l}0.87 \\
(0.54- \\
1.39)\end{array}$ & $\begin{array}{l}101 \\
(40.2)\end{array}$ & $\begin{array}{l}113 \\
(40.2)\end{array}$ & - & $\begin{array}{l}0.88 \\
(0.61- \\
1.26)\end{array}$ \\
\hline \multicolumn{9}{|l|}{$\begin{array}{l}\text { Radon } \\
\text { exposure }\end{array}$} \\
\hline $\begin{array}{l}<200 \\
\mathrm{~Bq} / \mathrm{m}^{3}\end{array}$ & $\begin{array}{l}74 \\
(56.5)\end{array}$ & $\begin{array}{l}140 \\
(62.5)\end{array}$ & - & $1(-)$ & $\begin{array}{l}146 \\
(58.2)\end{array}$ & $\begin{array}{l}175 \\
(62.3)\end{array}$ & - & $1(-)$ \\
\hline $\begin{array}{l}>=200 \\
\mathrm{~Bq} / \mathrm{m}^{3}\end{array}$ & $\begin{array}{l}57 \\
(43.5)\end{array}$ & $\begin{array}{l}84 \\
(37.5)\end{array}$ & - & $\begin{array}{l}1.38 \\
(0.88- \\
2.17)\end{array}$ & $\begin{array}{l}105 \\
(41.8)\end{array}$ & $\begin{array}{l}106 \\
(37.7)\end{array}$ & - & $\begin{array}{l}1.19 \\
(0.84- \\
1.7)\end{array}$ \\
\hline
\end{tabular}

${ }^{a}$ Adjusted for age.

${ }^{b}$ Adjusted for age, exposure to ETS, and residential radon.

AAT: alpha-1 antitrypsin.

ETS: environmental tobacco smoke. 


\section{Discussion}

This study, which analyses the possible relationship between AATD and risk of lung cancer in neversmokers, is based on one of the largest sample sizes reported to date, in that it included 457 cases and 631 controls. No higher risk of lung cancer was found among individuals who were homozygous or heterozygous carriers of the most frequent AAT deficiency alleles $(P \mid \star S, P I Z Z)$ as compared to carriers of the normal genotype $(\mathrm{PI} \mathrm{MM})$. Similarly, no effect was observed for subjects by sex or age group.

These results are in contrast with those obtained in a previous study published in 2015 by Torres-Durán et al. (24), using a similar population, albeit with a smaller sample size, in which an increased risk of LC was found in homozygous S allele carriers (PI*SS) (OR: $4.6495 \% \mathrm{Cl}=1.08-19.92)$. This risk was higher in women (OR: 7.58: 95\% Cl 1.40-40.87) and subjects with exposure to ETS (OR: 12.10; 95\% Cl 1.18-123.77).

In the last 30 years, different studies have been conducted with the principal aim of analysing the possible increase in risk of LC associated with AATD. They have fundamentally been undertaken in the USA and Europe, and among these mention should be made of the results of Yang et al. (26), who conducted a casecontrol study in the USA, which observed a $70 \%$ increase in risk of LC associated with AAT deficiency genotypes, with predominance of adenocarcinoma and squamous cell carcinoma lineages. In a casecontrol study conducted on the Serbian population, Topic et al. (27) observed that being a carrier of an AAT deficiency genotype increased the risk of squamous cell carcinoma (OR: 4.51 IC95\%=1.66-12.29). Recently, a systematic review was published (23), which included 6 studies with more than 4,000 patients and whose results suggest the existence of a relationship between AATD and risk of LC. This risk could be higher in individuals exposed to tobacco smoke and in those with diagnosis of COPD. This might be linked to the effects of AATD at a pulmonary level and their close relationship with tobacco use, which is the principal factor implicated in early development of emphysema in patients with severe AATD. Indeed, some studies have highlighted the association between pulmonary emphysema and risk of lung cancer (28).

Different mechanisms have been proposed which could be implicated in this association (19). Among these, one of the most important relates to pulmonary damage caused by the decrease in plasma AAT concentrations, which gives rise to a protease-antiprotease imbalance and, in turn, favours the development of an inflammatory state that promotes carcinogenesis and tumour progression (18). Another of the mechanisms proposed would be air trapping associated with pulmonary emphysema, since this could increase the time of contact with agents inhaled through the airway, thus increasing exposure to environmental carcinogens (29) and, by extension, to all those contained in tobacco smoke.

Analysing the possible causes that would account for the fact that the current study does not show an association between risk of LC and being a carrier of AAT deficiency alleles, when compared to the results of the previous study (24) which reported an increased risk of LC in patients who were carriers of the SS genotype, various factors could be considered: firstly, the current study found a smaller percentage of $S$ allele carriers than did the previous study (21.9\% currently vs. $25.9 \%)$, and the same applies to Z allele carriers $(3.7 \%$ currently vs. $5.2 \%)$. Likewise, the percentage of patients exposed to ETS was also smaller. 
The current study also found no evidence of an increased risk of LC associated with AATD in the analysis by subgroups according to age or sex. In the previous study (24), this risk was higher among women (OR: $7.5895 \% \mathrm{Cl} 1.40-40.87 ; \mathrm{p}=0.02$ ), though it has to be said that the analysis was not performed in men due to the small number included (18.9\%), a percentage which in the current study rose slightly, i.e., to $20.3 \%$. To our knowledge, there is no epidemiological evidence to show that the distribution of carriers of AAT deficiency alleles in a given geographical area might be different in the two sexes. That said, however, the fact that women had a higher incidence of $S$ allele carriers might account for these results. In contrast, the current study's larger sample size is an indicator of greater statistical power when it comes to the validity of its results.

We analysed the characteristics of the nine cases of LC in which the PI*SS genotype was found, in view of its previously observed association with an increased risk of LC. In this sample, all but one of the cases of LC associated with a PI*SS genotype appeared in women, with $55 \%$ being adenocarcinomas and $45 \%$ being squamous cell carcinoma. Adenocarcinoma is the most frequent histological type in never-smokers, in some series attaining percentages of more than $70 \%$ (24). Taken overall, of the cases included in this study, $77.5 \%$ were adenocarcinomas and only $7.7 \%$ corresponded to squamous cell carcinoma. Yet these relative frequencies were different in this subgroup of patients who were carriers of the PI*SS genotype, with the high proportion of squamous cell carcinoma warranting special mention, in view of the fact that these patients were never-smokers. These data agree with the results of previous studies that have analysed the relationship between AATD and LC: Topic et al. (27) identified an increased risk of squamous cell carcinoma $(\mathrm{OR}=4.51 ; 95 \% \mathrm{Cl}=1.6612 .29)$ in carriers of the $\mathrm{PI}{ }^{\star} \mathrm{MZ}$ and $\mathrm{PI} \mathrm{MS}^{*}$ genotypes; Yang et al. (30) observed an increased risk of adenocarcinoma in carriers of AAT deficiency alleles, bronchoalveolar carcinoma $(\mathrm{OR}=2 ; 95 \% \mathrm{Cl}=1.13 .8)$ and squamous cell carcinoma in particular $(\mathrm{OR}=2.5 ; 95 \% \mathrm{Cl}=1.25 .3)$; and Li et al. (21) also detected 55.3\% of adenocarcinomas. None of these 9 patients suffered from COPD, and high-resolution computed tomography showed no presence of emphysema.

The advantages of our study are, firstly, its sample size, which is one of the largest reported to date and practically doubles the number used in our previously conducted study, including a greater number of men which thus made it possible to analyse their risk, unlike the earlier study. The exclusive use of neversmokers meant that possible biases in the interpretation of results attributable to tobacco use could be ruled out. Indeed, this and the previous study are the only ones published to date to have analysed the risk of LC associated with AATD in never-smokers. A further advantage was having access to measurements of residential radon levels, which constitute the main risk factor for $L C$ in never-smokers and thus enabled the association between AATD and LC to be established with greater certainty.

The principal limitation of our study is common to all studies of rare diseases, in this case AATD, and relates to the low overall prevalence of the disorder, which means that the number of carriers of deficiency alleles is inevitably small irrespective of the size of sample used. Furthermore, not having plasma AAT levels means that there is the possibility that some of the genotypes rated normal by PCR might correspond to rare or null deficiency alleles, though this finding would be somewhat exceptional. Lastly, respiratory function or emphysema status was not specifically analysed in this study, something that might have been 
of interest in order to examine its role as an intermediary agent in lung cancer among never-smokers potentially associated with AAT deficiency.

\section{Conclusions}

In conclusion, this study was unable to demonstrate an association between being a carrier of an AAT deficiency genotype and risk of LC in never-smokers: similarly, no association was shown in the analysis by age, sex, or exposure to ETS. Given that there are no other studies of these characteristics conducted on never-smokers, this could imply that AAT deficiency may only play a role in carcinogenesis of LC in smokers or ex-smokers and may have no influence in the case of never-smokers. Hence, tobacco use could act as an effect modifier in relation to the presence of this deficiency in the genesis of lung cancer. To respond to this question, other studies will have to be conducted on other populations having a different genetic base. Moreover, future research along these lines should consider exposure to residential radon, in order to be able to accurately establish the effect of AAT deficiency on never-smokers.

\section{List Of Abbreviations}

LC: Lung cancer; AATD: Alpha-1 antitrypsin deficiency; ETS: Enviromental tobacco smoke; AAT: Alpha-1 antitrypsin; COPD: Chronic obstructive pulmonary disease; FEV1: Forced expiratory volume in the first second; DLCO: Diffusing capacity of the lung for carbon monoxide; PI: Protease inhibitor; PCR: Polymerase chain reaction.

\section{Declarations}

\section{Ethics approval and consent to participate}

The authors are accountable for all aspects of the work in ensuring that questions related to the accuracy or integrity of any part of the work are appropriately investigated and resolved. The study protocol was approved by the Galician Ethics Committee (2010/295) and all participants signed a written consent to participate in this research. No illiterate participants were involved in this study.

\section{Consent for publication}

Not applicable.

\section{Availability of data and materials}

The datasets used and/or analysed during the current study are available from the corresponding author on reasonable request.

\section{Competing interests}

The authors declare that they have no competing interests. 


\section{Funding}

This work was supported by a competitive research grant offered by the Xunta de Galicia [10CSA2080057PR] "Risk factors of lung cancer in never smokers: a multicenter case-control study in the Northwest of Spain”, partially supported by the Instituto de Salud Carlos III. [PI13/01765]. "Molecular genetic profile of DNA repair markers (BER and NER) and biological risk of lung cancer from residential radon exposure: A case-control study", partially supported by Instituto de Salud Carlos III, Ministry of Science and Innovation of Spain [PI15/01211]. (Year 2015) and another from the same institution [PI031248] (Year 2012). “Residential Radon Exposure, Histologic Types, and Lung Cancer Risk. A CaseControl Study in Galicia, Spain".

\section{Author's contributions}

I. Conception and design: CCP, JRB, MPR, JBD and ARR

II. Administrative support: CCP, JRB, MPR, JBD and ARR

III. Provision of study materials or patients: CCP, JRB, MPR, JBD and ARR

IV. Collection and assembly of data: CCP, JRB, MPR, JBD and ARR

V. Data analysis and interpretations: CCP, JRB, MPR, JBD and ARR

VI. Manuscript writing: All authors

VII. Final approval of manuscript: All authors

\section{Acknowledgments}

The genotyping service was accomplished at CEGEN-PRB3-ISCIII; it is supported by grant PT17/0019, of the PE I + D + I 2013-2016, funded by ISCIII and ERDF.

This study is part of the work aimed of the completion of the PhD Degree of Ramón A. Tubío-Pérez.

\section{Footnote}

We present the following article in accordance with the STROBE reporting checklist.

\section{References}

1. Mao Y, Yang D, He J, Krasna MJ. Epidemiology of Lung Cancer. Surg Oncol Clin N Am. 2016;25:43945.

2. Barta JA, Powell CA, Wisnivesky JP. Global Epidemiology of Lung Cancer. Ann Glob Health;85.

3. Allemani C, Matsuda T, Di Carlo V, et al. Global surveillance of trends in cancer survival 2000-14 (CONCORD-3): analysis of individual records for 37513025 patients diagnosed with one of 18 cancers from 322 population-based registries in 71 countries. Lancet Lond Engl;391:1023-75.

4. Torres-Durán M, Barros-Dios JM, Fernández-Villar A, et al. Residential radon and lung cancer in never smokers. A systematic review. Cancer Lett;345:21-6. 
5. Pelosof L, Ahn C, Gao A, et al. Proportion of Never-Smoker Non-Small Cell Lung Cancer Patients at Three Diverse Institutions. J Natl Cancer Inst. 2017;109.

6. Clément-Duchêne $C$, Vignaud J-M, Stoufflet $A$, et al. Characteristics of never smoker lung cancer including environmental and occupational risk factors. Lung Cancer Amst Neth;67:144-50.

7. Wu D-M, Liu T, Deng S-H, et al. Alpha-1 Antitrypsin Induces Epithelial-to-Mesenchymal Transition, Endothelial-to-Mesenchymal Transition, and Drug Resistance in Lung Cancer Cells. OncoTargets Ther. 2020.doi.org/10.2147/OTT.S242579

8. Mehta A, Dobersch S, Romero-Olmedo AJ, et al. Epigenetics in lung cancer diagnosis and therapy. Cancer Metastasis Rev;34:229-41.

9. Mornex JF, Chytil-Weir A, Martinet $Y$, et al. Expression of the alpha-1-antitrypsin gene in mononuclear phagocytes of normal and alpha-1-antitrypsin-deficient individuals. J Clin Invest;77:1952-61.

10. Long GL, Chandra T, Woo SL, et al. Complete sequence of the CDNA for human alpha 1-antitrypsin and the gene for the $S$ variant. Biochemistry;23:4828-37.

11. American Thoracic Society, European Respiratory Society. American Thoracic Society/European Respiratory Society statement: standards for the diagnosis and management of individuals with alpha1 antitrypsin deficiency. Am J Respir Crit Care Med;168:818-900.

12. Fagerhol MK, Laurell CB. The polymorphism of «prealbumins» and alpha-1-antitrypsin in human sera. Clin Chim Acta Int J Clin Chem;16:199-203.

13. Kueppers F, Christopherson MJ. Alpha1-antitrypsin: further genetic heterogeneity revealed by isoelectric focusing. Am J Hum Genet;30:359-65.

14. de Serres F, Blanco I. Role of alpha-1 antitrypsin in human health and disease. J Intern Med;276:31135.

15. Sinden NJ, Baker MJ, Smith DJ, et al. a-1-antitrypsin variants and the proteinase/antiproteinase imbalance in chronic obstructive pulmonary disease. Am J Physiol Lung Cell Mol Physiol;308:L179190.

16. Lewis EC. Expanding the clinical indications for a(1)-antitrypsin therapy. Mol Med Camb Mass;18:95770.

17. Chan ED, Pott GB, Silkoff PE, et al. Alpha-1-antitrypsin inhibits nitric oxide production. J Leukoc Biol;92:1251-60.

18. Sun Z, Yang P. Role of imbalance between neutrophil elastase and alpha 1-antitrypsin in cancer development and progression. Lancet Oncol;5:182-90.

19. Shakya R, Tarulli GA, Sheng L, et al. Mutant p53 upregulates alpha-1 antitrypsin expression and promotes invasion in lung cancer. Oncogene. 2017;36:4469-80.

20. Lomas DA, Mahadeva R. Alpha1-antitrypsin polymerization and the serpinopathies: pathobiology and prospects for therapy. J Clin Invest;110:1585-90.

21. Li Y, Krowka MJ, Qi Y, et al. Alpha1-antitrypsin deficiency carriers, serum alpha 1-antitrypsin concentration, and non-small cell lung cancer survival. J Thorac Oncol Off Publ Int Assoc Study Lung Cancer;6:291-5. 
22. Harris $\mathrm{CC}$, Cohen $\mathrm{MH}$, Connor R, et al. Serum alpha1-antitrypsin in patients with lung cancer or abnormal sputum cytology. Cancer;38:1655-7.

23. Tubío-Pérez RA, Torres-Durán M, Fernández-Villar A, et al. Alpha-1 antitrypsin deficiency and risk of lung cancer: A systematic review. Transl Oncol;14:100914.

24. Torres-Durán M, Ruano-Ravina A, Parente-Lamelas I, et al. Alpha-1 Antitrypsin Deficiency and Lung Cancer Risk: A Case-Control Study in Never-Smokers. J Thorac Oncol Off Publ Int Assoc Study Lung Cancer;10:1279-84.

25. Buetow KH, Edmonson M, MacDonald R, et al. High-throughput development and characterization of a genomewide collection of gene-based single nucleotide polymorphism markers by chip-based matrixassisted laser desorption/ionization time-of-flight mass spectrometry. Proc Natl Acad Sci U SA.998:581-4.

26. Yang P, Sun Z, Krowka MJ, et al. Alpha1-antitrypsin deficiency carriers, tobacco smoke, chronic obstructive pulmonary disease, and lung cancer risk. Arch Intern Med;168:1097-103.

27. Topic AS, Jelic-lvanovic ZD, Spasojevic-Kalimanovska VV, et al. Association of moderate alpha-1 antitrypsin deficiency with lung cancer in the Serbian population. Arch Med Res;37:866-70.

28. Tubío-Pérez RA, Torres-Durán M, Pérez-Ríos M, et al. Lung emphysema and lung cancer: what do we know about it? Ann Transl Med;8:1471.

29. Cosio MG, Bazzan E, Rigobello C, et al. Alpha-1 Antitrypsin Deficiency: Beyond the Protease/Antiprotease Paradigm. Ann Am Thorac Soc. 2016;13 Suppl 4:S305-310.

30. Yang P, Wentzlaff KA, Katzmann JA, et al. Alpha1-antitrypsin deficiency allele carriers among lung cancer patients. Cancer Epidemiol Biomark Prev Publ Am Assoc Cancer Res Cosponsored Am Soc Prev Oncol.;8:461-5. 